\title{
Czesław Wolek
}

dr inż.

Politechnika Wrocławska, Wydział Budownictwa Lądowego i Wodnego,

Zakład Dróg i Lotnisk

czeslaw.wolek@pwr.edu.pl

\section{Sebastian Kowerski}

mgr inż.

Politechnika Wrocławska, Wydział Budownictwa Lądowego i Wodnego, Zakład Dróg i Lotnisk

sebastian.kowerski@pwr.edu.pl

DOI: 10.35117/A_ENG_16_09_03

\section{Influence of traffic lights on tram's time losses in a tram stop area}

\begin{abstract}
The paper presents an analysis of the impact of the location of the tram stop at intersections and near pedestrian crossings located on the sections between intersections equipped with traffic lights on the values of time lost. The research was performed in Wrocław, on the two tram stops (Pereca and Grunwaldzki Bridge) characterized by a similar location of tram stop within intersection, and on the two tram stops located on the section between the intersections with traffic lights, before (Hutmen) and behind (Bzowa) pedestrian crossing.

Due to the time lost associated with waiting for the signal enabling entry to or exit from the tram, the location of the bus stop behind traffic lights is more advantageous.
\end{abstract}

Keywords: Traffic lights; Time lost; Tram stop; Tram

\section{Introduction}

In Poland, tram entered re-development time as a mode of urban transport after the period of stagnation in the $90 \mathrm{~s}$ of the last century. The advantages of the tram may include: greater capacity than bus, longer life and less harmful impact on the environment. The use of lowfloor trams resulted in an increase in the comfort of travel for people with disabilities as well as other participants in the trip. Higher operating parameters of the trams make that an old type trams are a problem in traffic. To maximally use traction parameters and avoid a mixed traffic of trams currently exploiting and new rolling stock in Wroclaw, low-floor trams took transport on newly constructed or upgraded trackways after outside the city centre characterized by the large streams travel. The methodology of the organization transit stops including the possibility of mutual connection of coming trams and designing the platforms was presented in [5]. Analysis of factors influencing the safety and comfort of travellers, depending on the location and conditions related to the disembarking and embarking on a tram, were discussed in $[1,2,3]$. When assessing the quality of trams, one of factors is the travel comfort including travel conditions, especially with regard to: the availability of stops, the frequency of connections, punctuality and time travel. The travel time depends on the operating speed, which is a function of speed, time, exchange of passengers and wasted time. The subject of the discussion in this article is the influence of the location of the stops and the traffic lights on the loss of tram time. 


\section{Types of stops}

The methods of forming solutions for trams and their location in respect to the intersection and streets are discussed in $[1,6,8]$. In Wroclaw, the most commonly used solutions of tram stops are:

- stops without separate islands - exchange of passengers is realized after stopping the tram from the roadway level directly adjacent to the sidewalk,

- stops with separate islands in the middle of the road or located in a separation strip between the roadways, at the trackway tram - access to the islands is by the pedestrian crossing at the level of the roadway, underpass or footbridge,

- stops of Vienna type- exchange of passengers is realized from the road level, uplifted along the stop to the sidewalk level,

- stops of bulb-type - stop platform is made by widening the sidewalk, at the expense of liquidation of lane along the stop: vehicles move along the trackway tram after the departure of the tram.

In the case of stops without separate islands (Fig. 1) exchange of passengers is carried out in the lane for cars, and the waiting area is located on the sidewalk. In order to enter the tram, it is necessary to pass through the lane which threatens the security especially in the case of using the last door of the vehicle. In addition, a significant difference in height between the roadway and the floor tram is to overcome even in the case of low-floor trams.

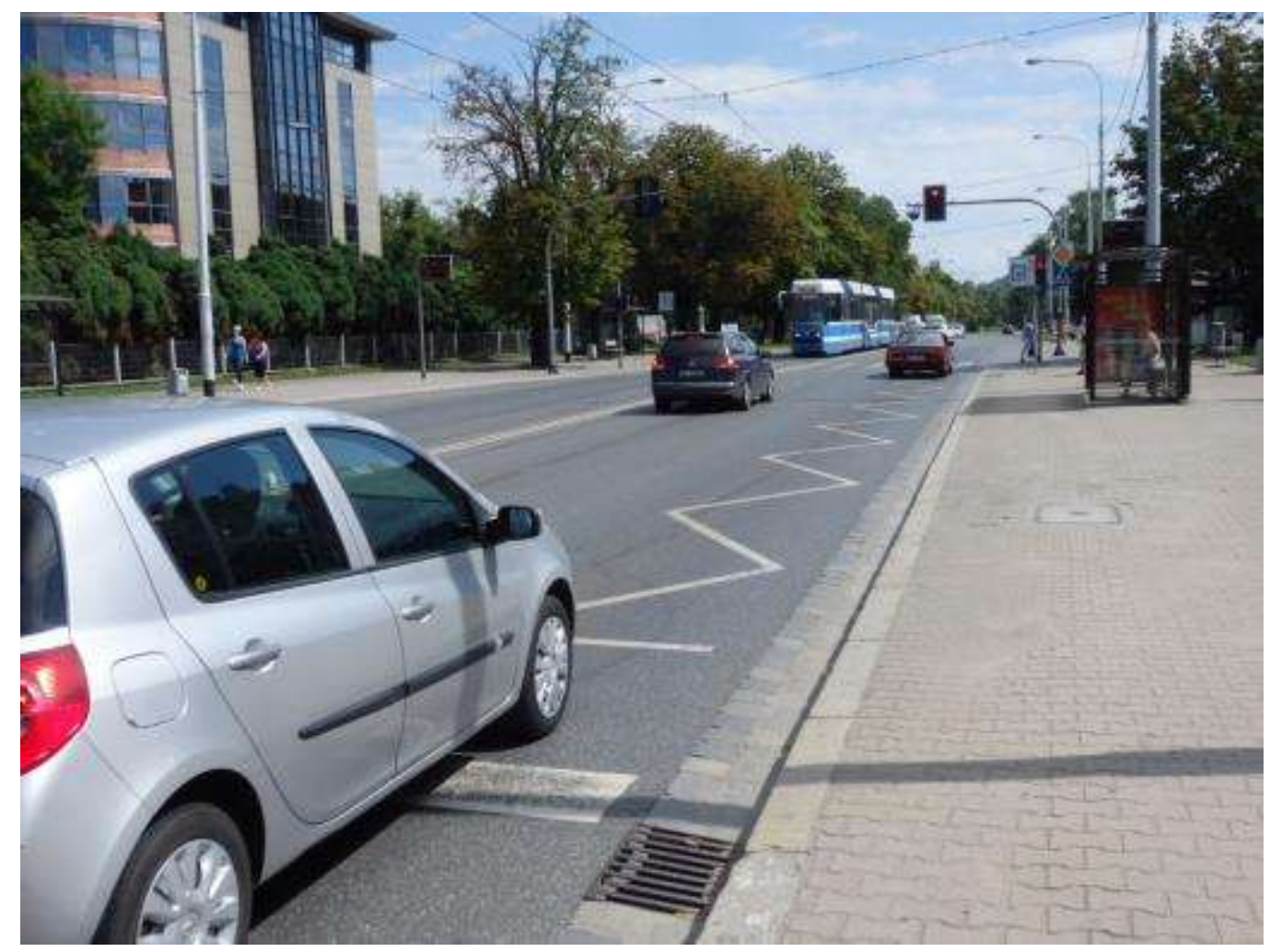

1. Tram stop without separate islands „Hutmen” at Grabiszyńska Stree in Wrocław (phot. Cz. Wolek)

The second type is stop with separate islands. A raised island in the road is the waiting surface for a vehicle. In this type of stop, it is important to provide a comfortable 
access to the platform at its beginning and end. It should be at the same time ensured an adequate width of the island platform, as it is pointed out by the authors in [4]. The creation of a safe waiting area, as well as the reduction of the height during embarking increases the comfort of exchange. The stop with the insular platform is shown in Fig. 2.

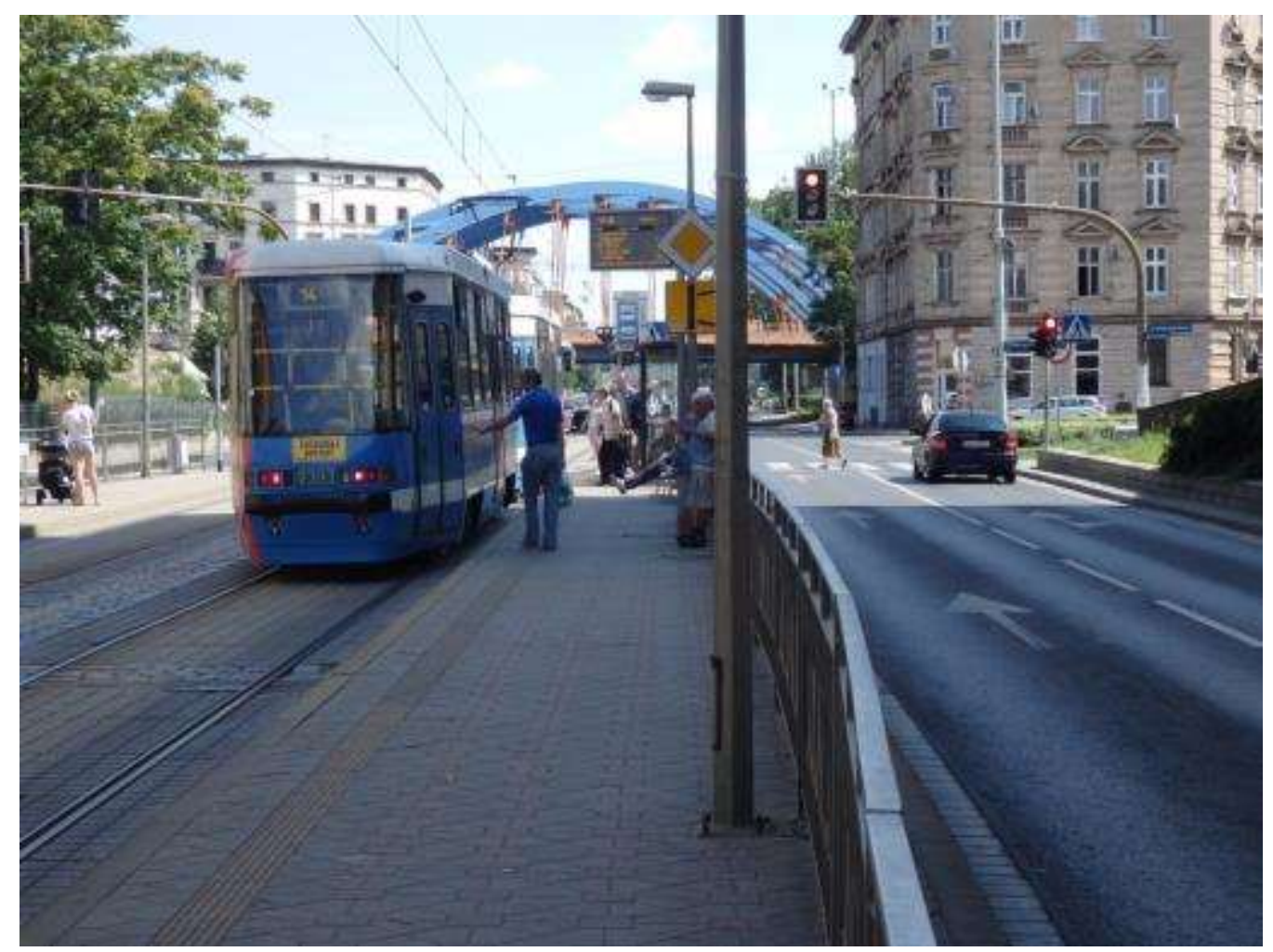

2. Tram stop with separate islands „Pereca” at Grabiszyńska Street in Wrocław (phot. Cz. Wolek)

Designing stops of Vienna type is becoming more popular to improve the safety of public transport during the exchange of passengers at the stop. This type of stop is characterized by a part of the road raised to the height of the pavement in the vicinity of the tram, serving also as the speed bump. On the other hand, by means of labelling, drivers stop in the front of elevation on the road and another tram waiting for the completion of passenger service. This solution improves the safety of all participants in traffic. The elevation of the platform surface facilitates and accelerates the exchange of passengers as a result of reducing the difference in the height between the surface of the platform and the floor of the tram. Nearby the Vienna stops are often designed pedestrian crossings to exploit the slowing in traffic. An example stop of Vienna type is presented in Fig. 3. 


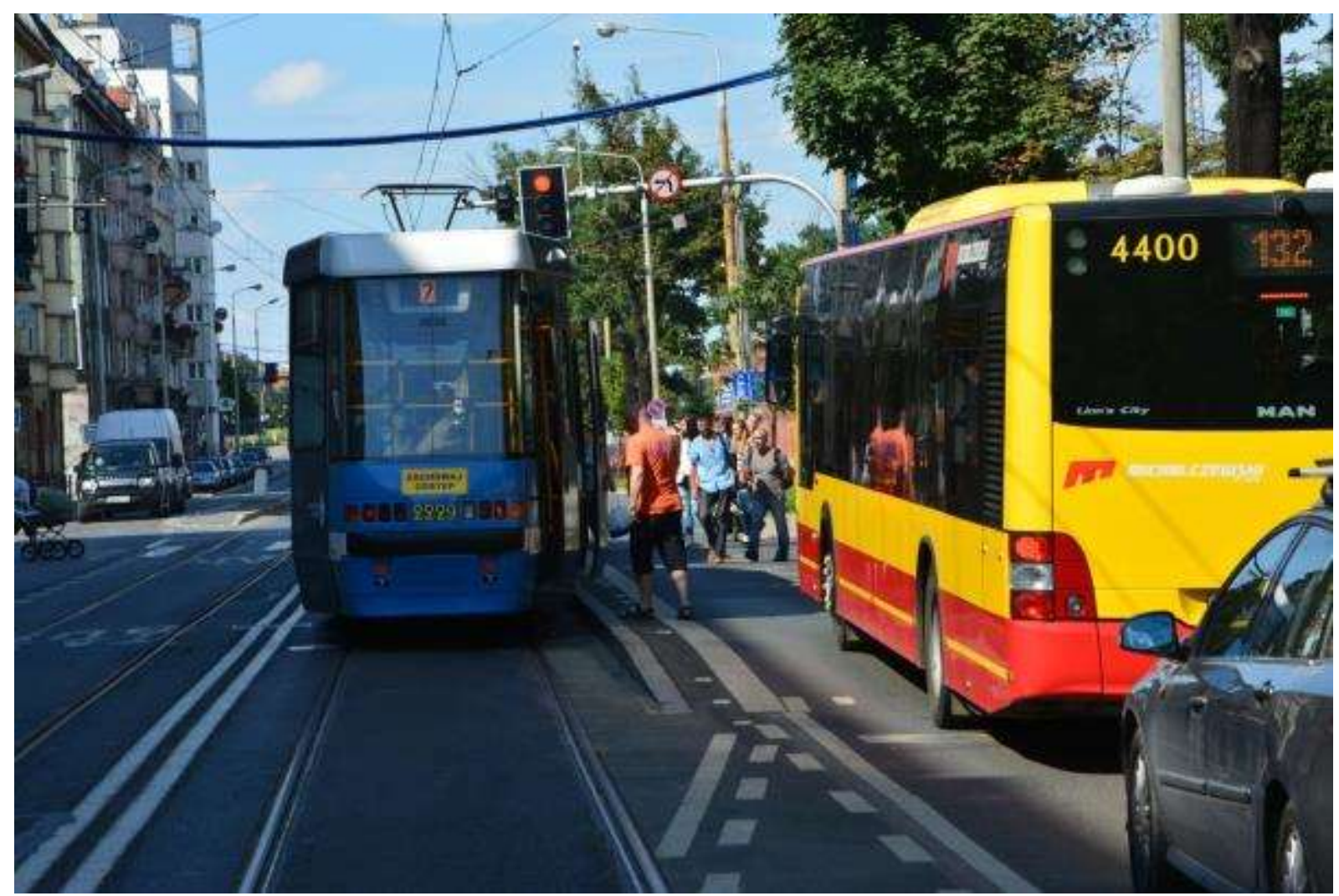

3. Tram stop of Vienna type „Trzebnicka” at Trzebnicka Street in Wrocław (phot. S. Kowerski)

Another type of stop, which allows to completely exclude conflict between pedestrian and vehicle is called bulb (Fig. 4). Stop of bulb-type, also called semi-island platforms or tram - bus islands, are part of the road in the form of a designated place for stopping vehicles of public transport where the road narrows and the pavement widens. This stop is built to calm the traffic in the area stop and increase the surface area for the exchange of passengers. The bulb, in the opposition to bus bay, is used in order to allow buses to stop besides the movement of other vehicles. However, in this case, a tram or bus stops other vehicles, providing a secure exchange of passengers [7]. 


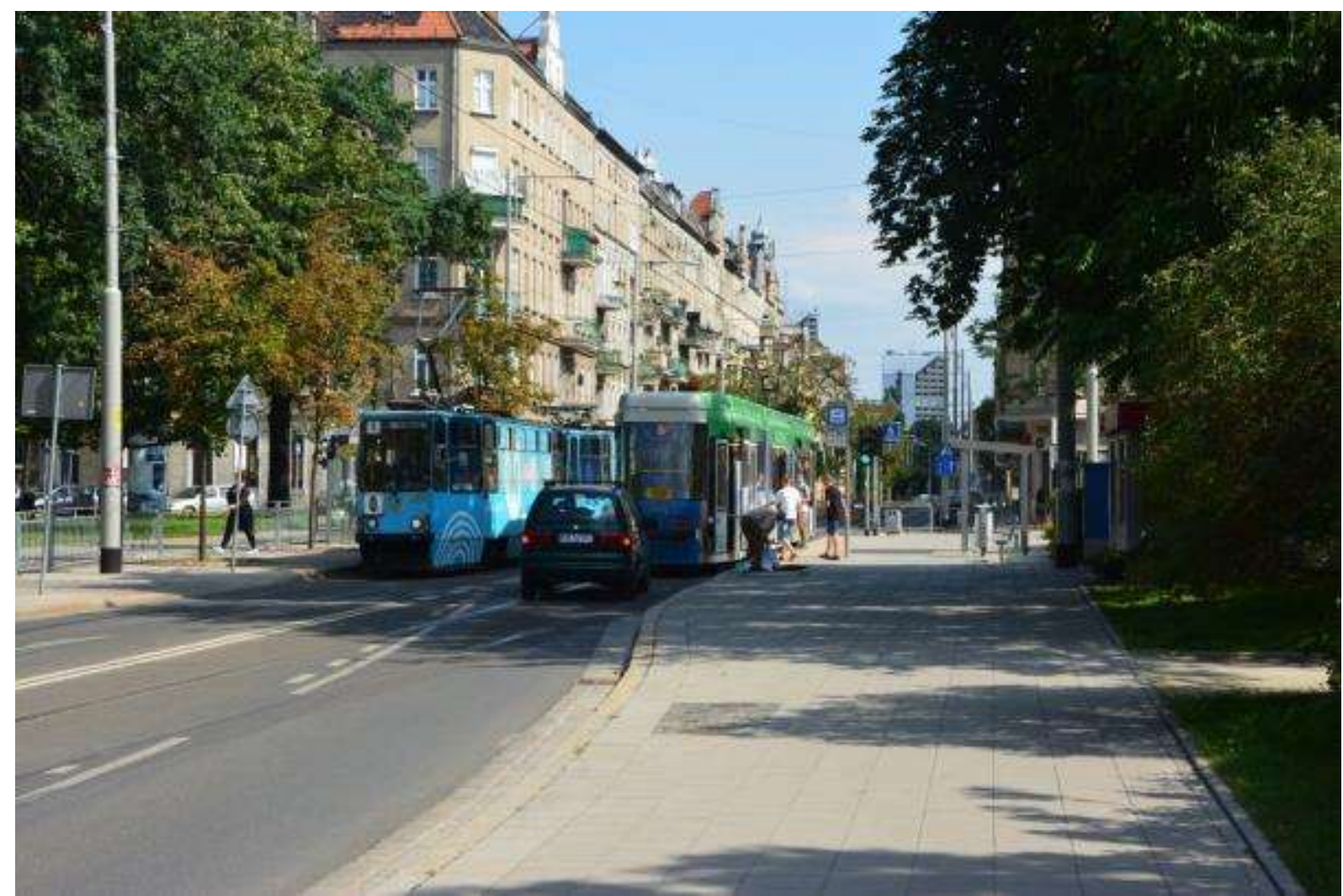

4. Tram stop of bulb-type „Prusa” at Nowowiejska in Wrocław (phot. S. Kowerski).

\section{Scope of the study}

The analysed stops are located in the southern part of the city of Wroclaw, along the street Grabiszyńska (Hutmen, Bzowa, Pereca) and the eastern sides of the city centre (Grunwaldzki Bridge). The studied stops were located in the area of two intersections with traffic lights after one side - on the inlet and outlet (Pereca and Grunwaldzki Bridge, Fig. 5 and 6) and two stops (Hutmen and Bzowa, Fig. 7 and 8) were placed in the area of pedestrian crossing with traffic lights (before and after the transition, respectively), located between the intersections. 


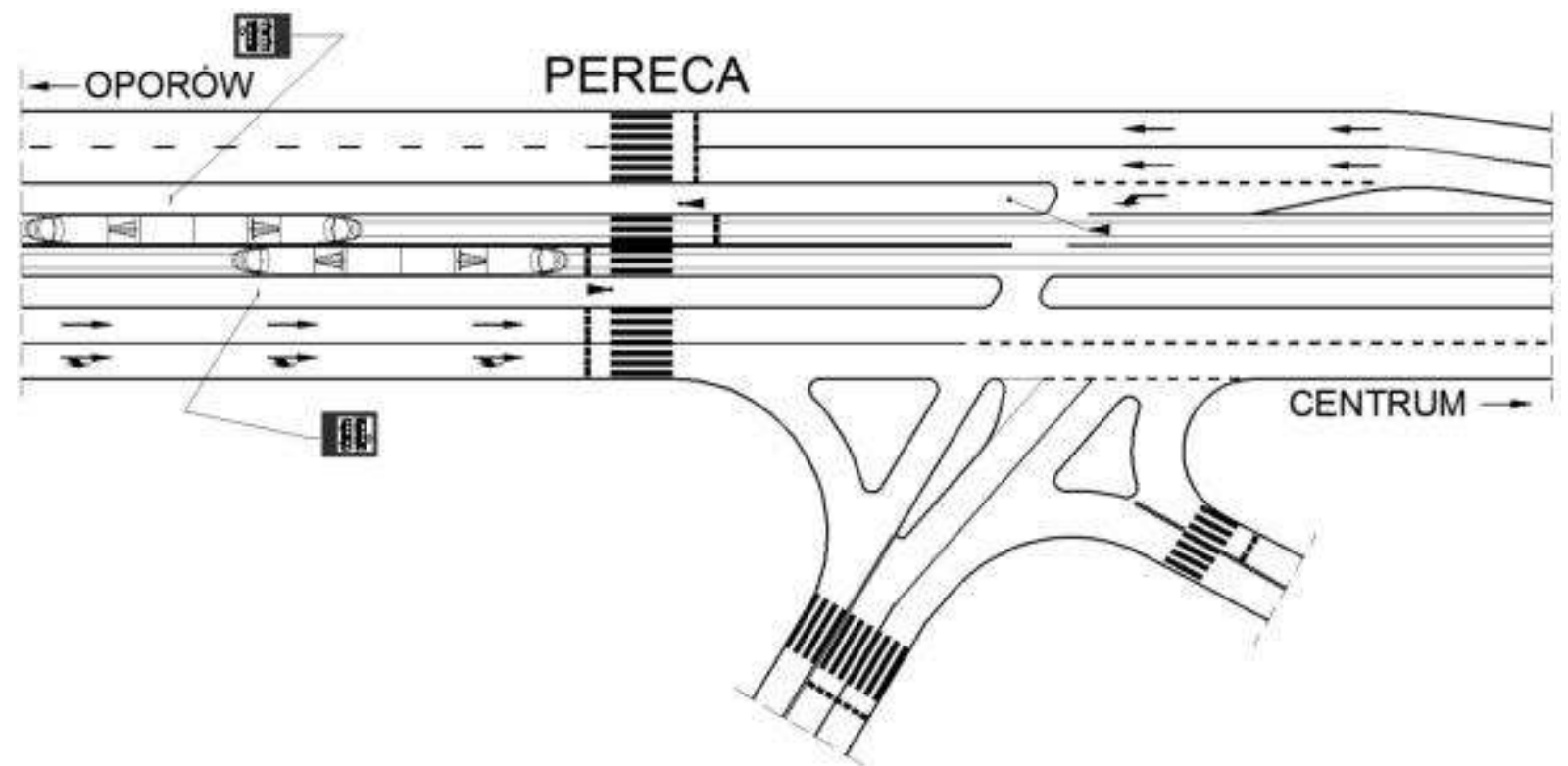

5. Schematic location of stops "Pereca" at the inlet and outlet of crossing (the figure includes signals only for tram).

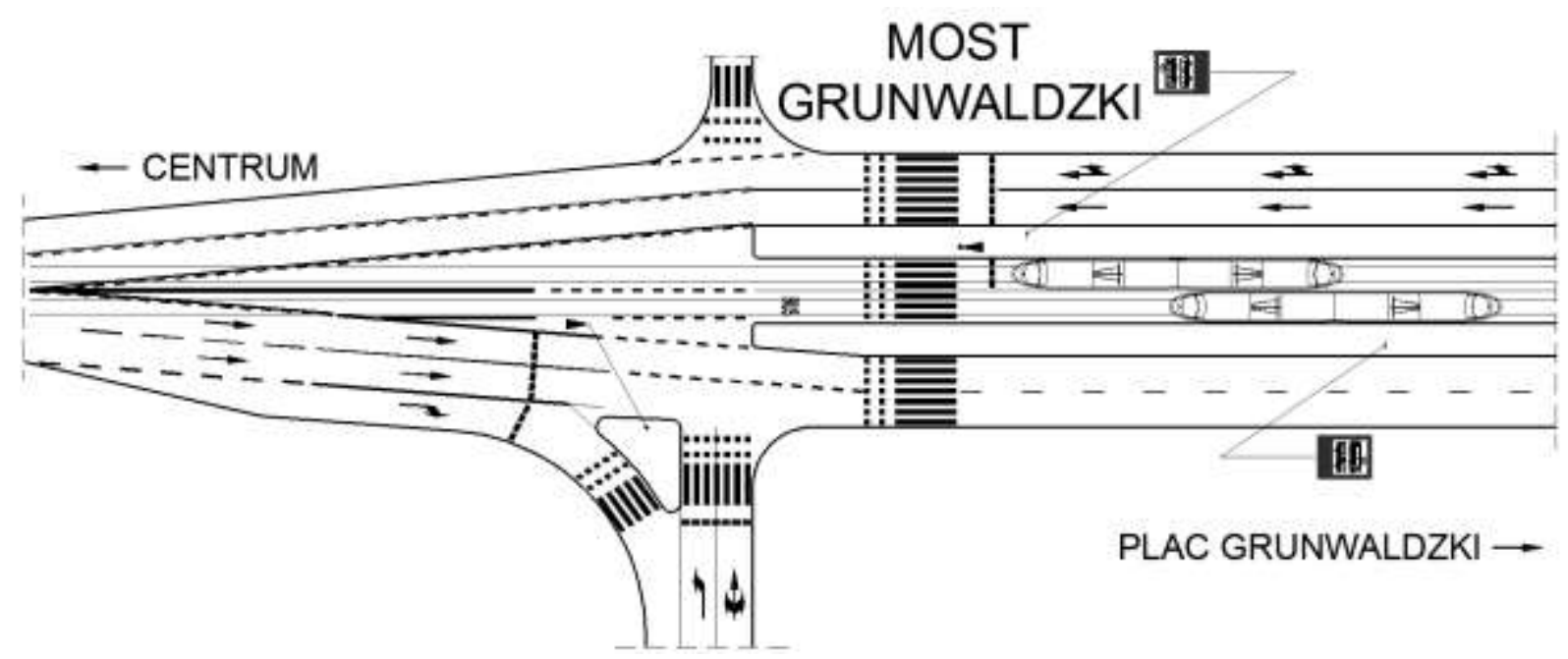

6. Schematic location of stops "Grunwaldzki Bridge" at the inlet and outlet of crossing (the figure includes signals only for tram)

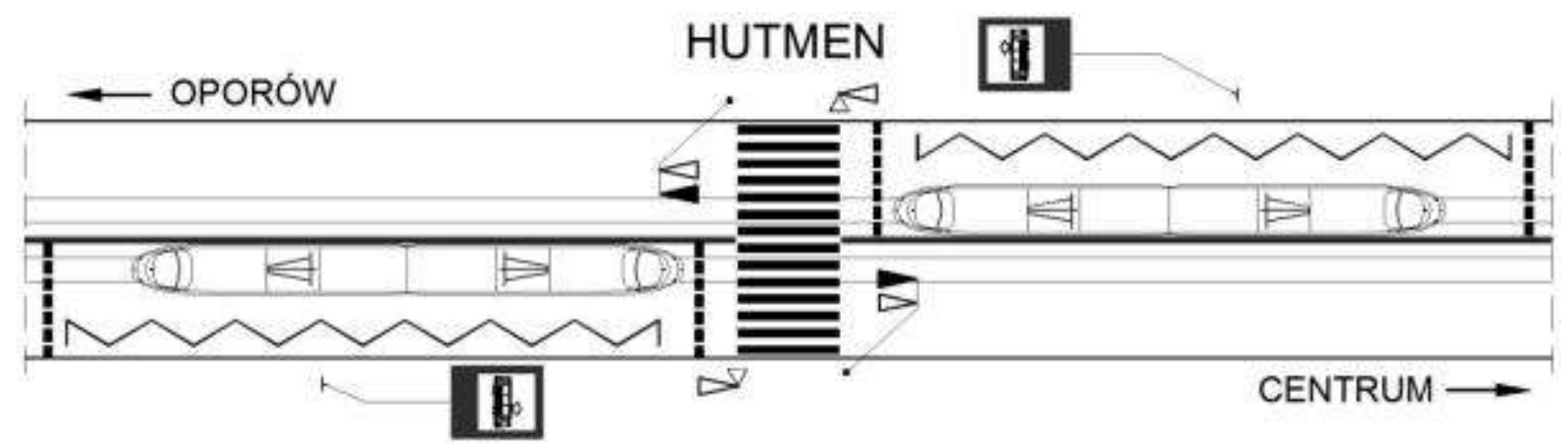

7. Schematic location of stops "Hutmen" in the front of pedestrian passing 


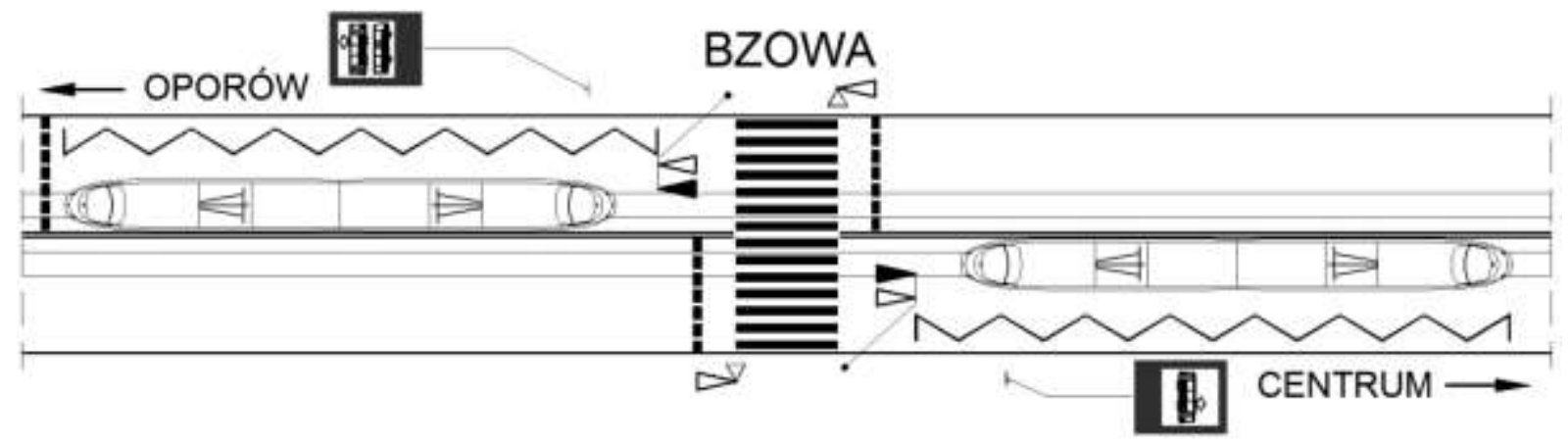

8. Schematic location of stops "Bzowa" behind pedestrian passing

Studies were carried out in working days, in the period from May to June 2015 and from February to March 2016. The frequency of trams during the measurements was from 16 to 20 trains per hour in each direction. In the case of stops with traffic lights, the value of time lost depends on the time of stopping the tram before the traffic light and the time elapsed since the end of the exchange passengers to leaving the stop. The obtained results are shown in Fig. 9a and 10a (at the outlet of crossing) and Fig. 11 (behind a pedestrian crossing with traffic lights). For stops located at the inlet of crossing with traffic lights or in the front of a pedestrian crossing with traffic lights on the node section, the analysis was subjected the lost time elapsed from the completion of the exchange of passengers till the departure of a tram from the stop, Fig. 9b and $\mathbf{1 0 b}$ (at the inlet of crossing) and Fig. 12 (in the front of the pedestrian crossing with traffic lights). 

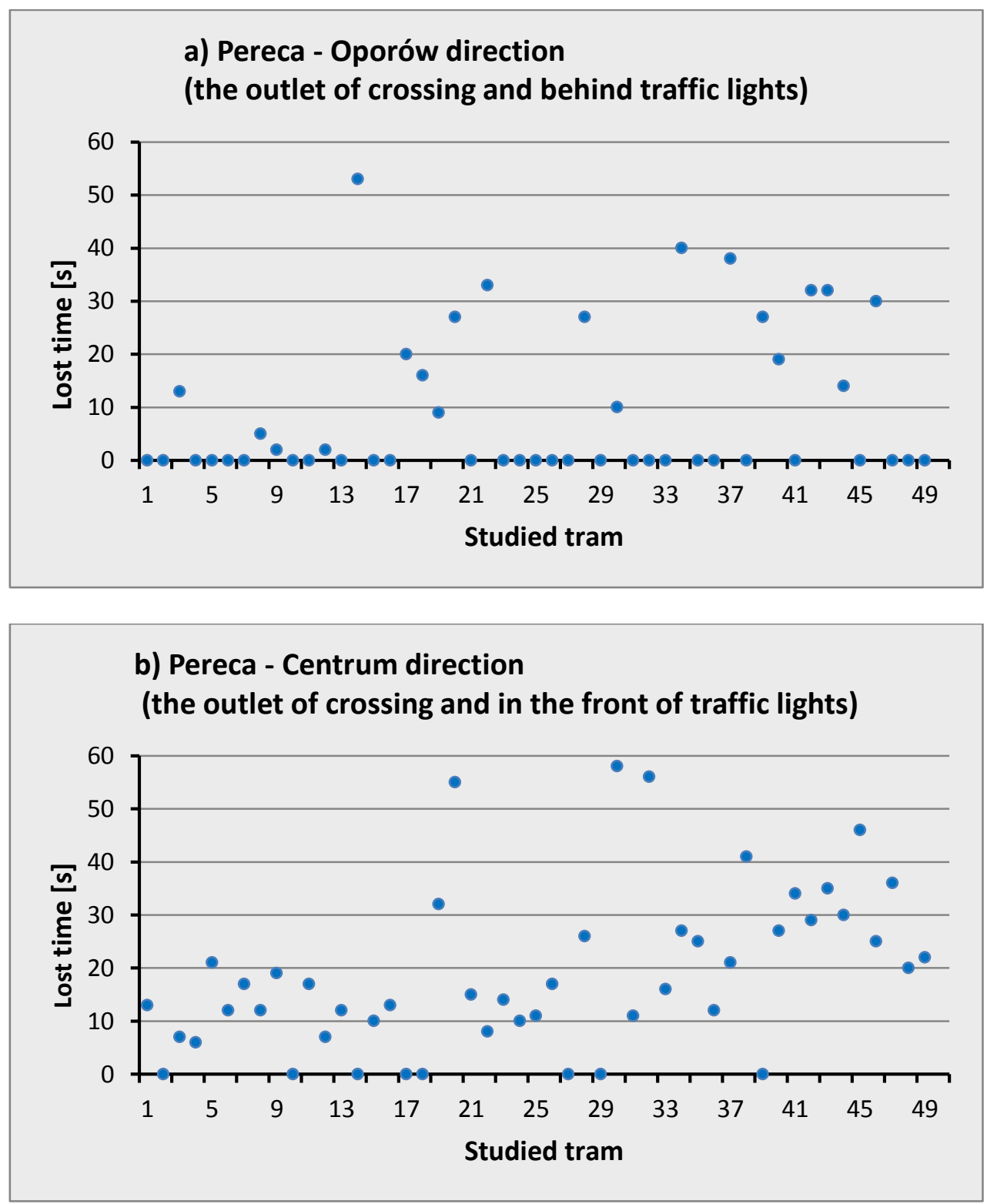

9. Loss of time at stops "Pereca" located at the inlet and outlet of crossing 

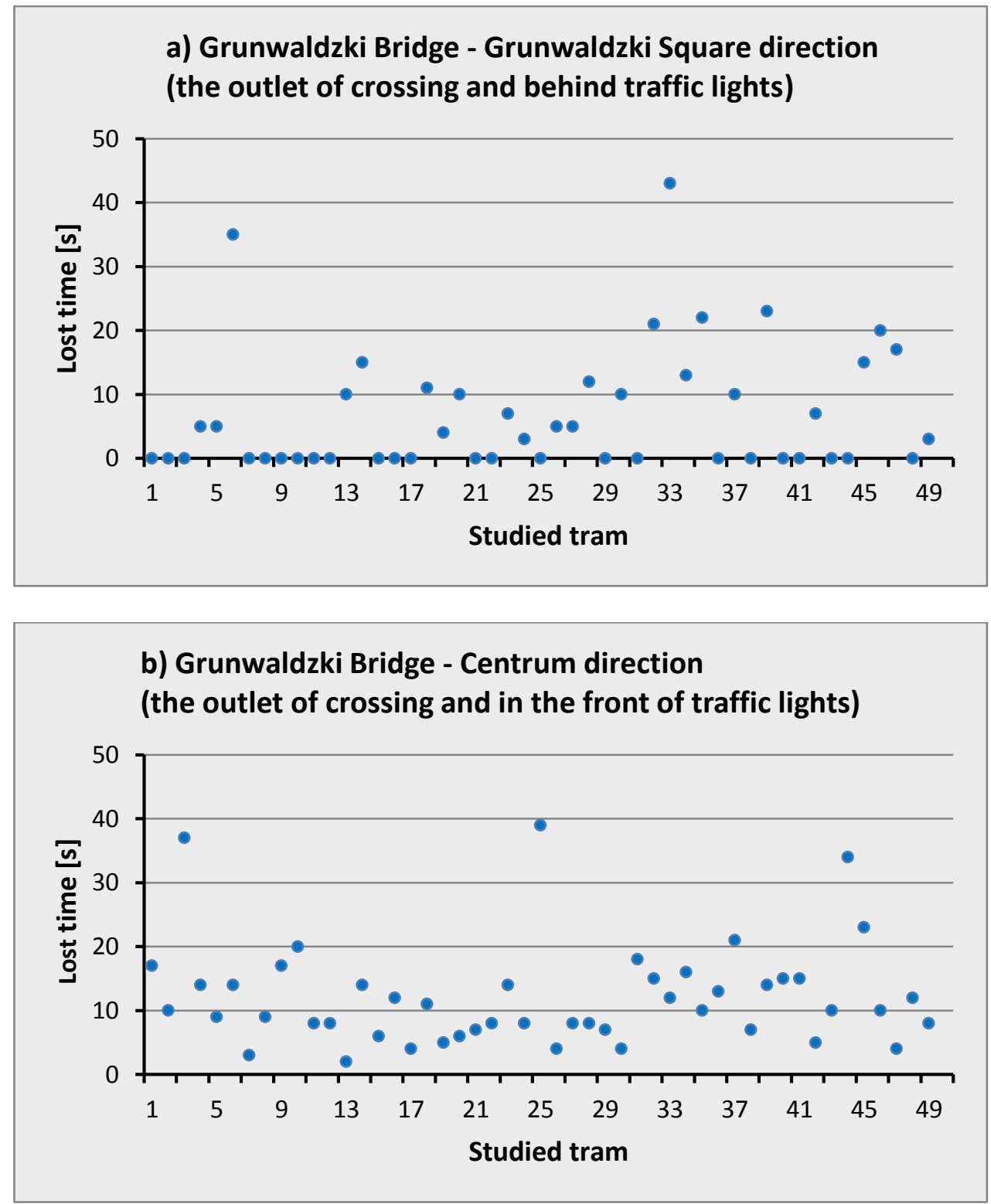

10. Loss of time at stops "Grunwaldzki Bridge" located at the inlet and outlet of crossing 

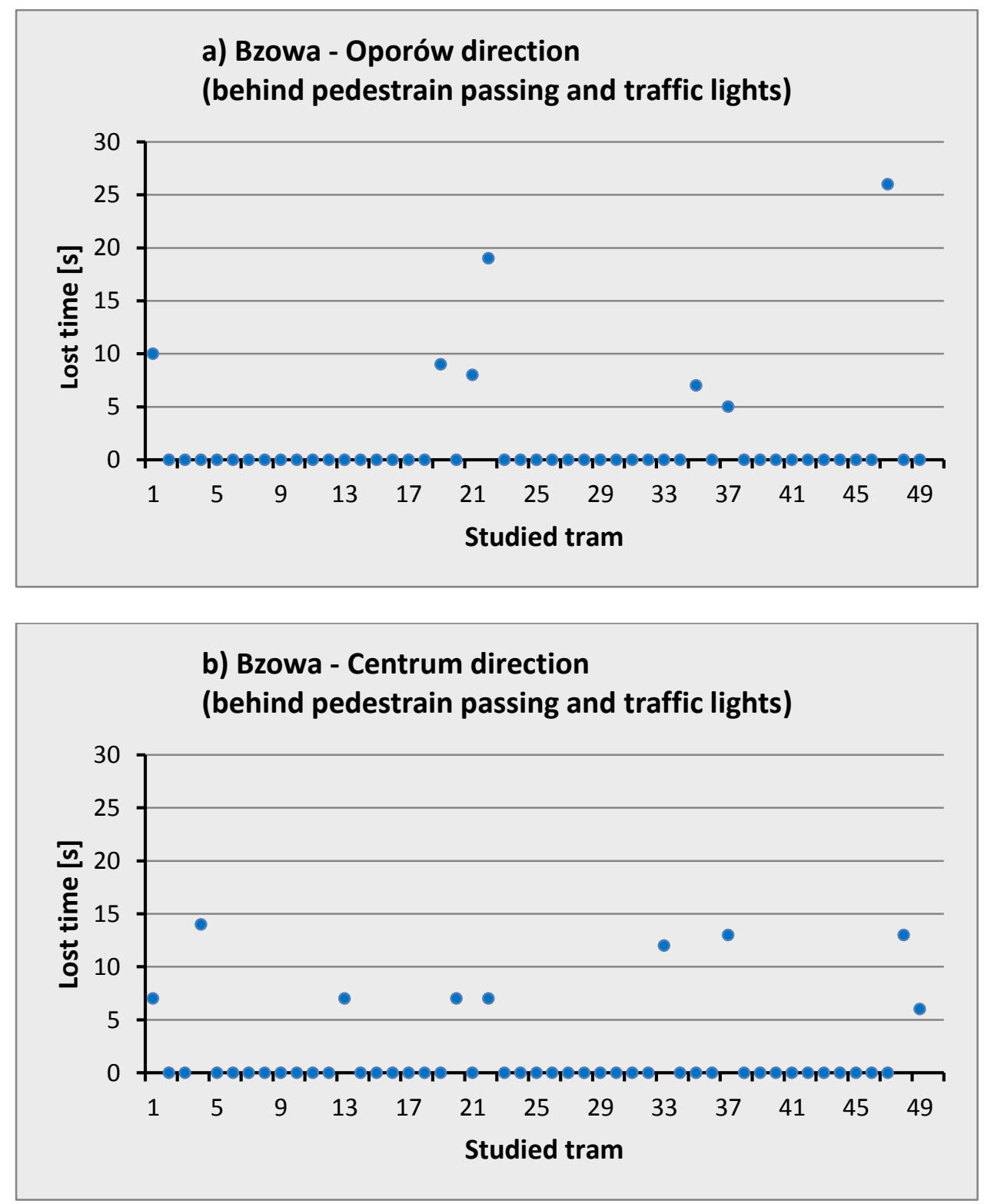

11. Loss of time at stops "Bzowa" located in two directions behind pedestrian crossing 

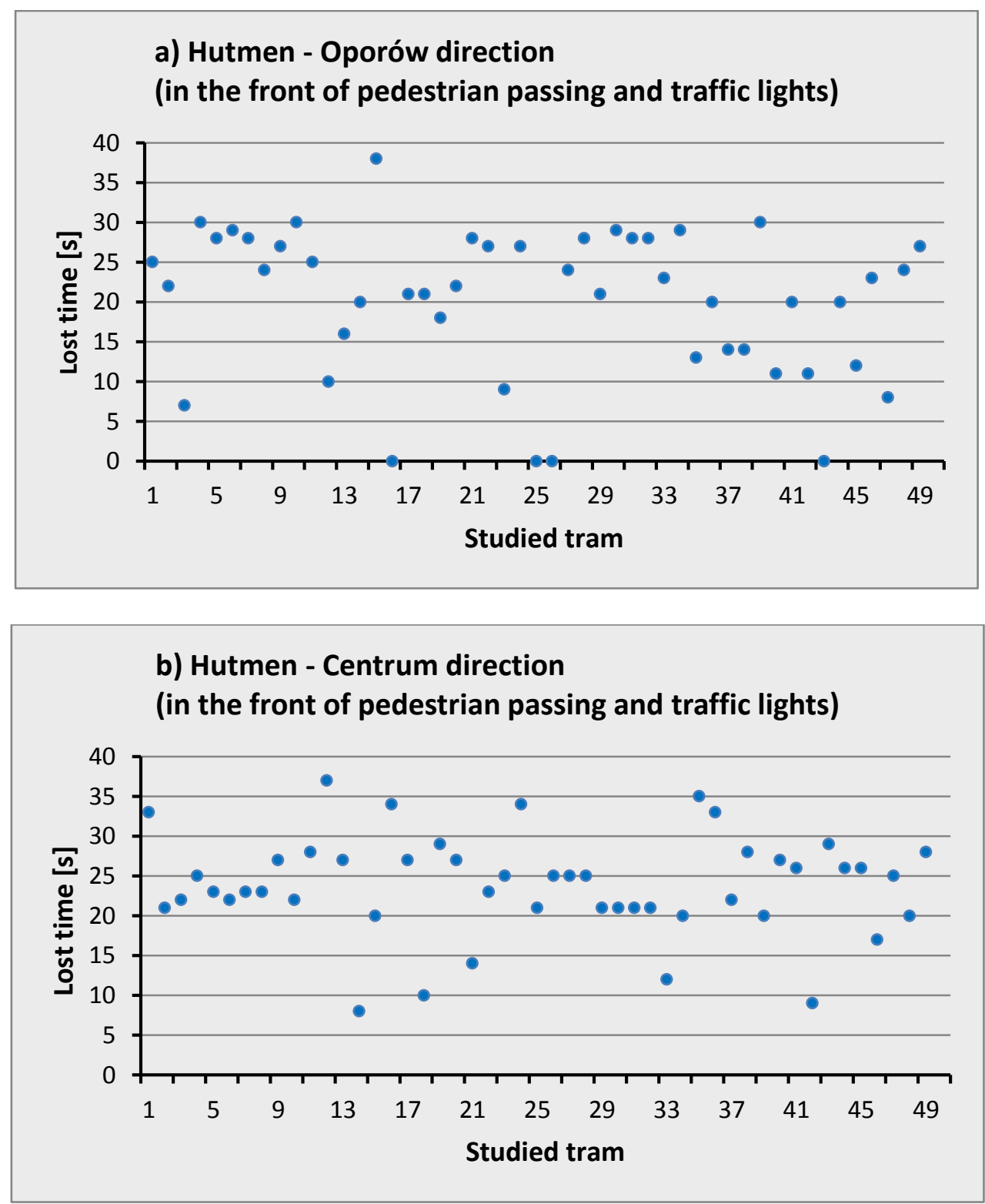

12. Loss of time at stops "Hutmen" located in two directions in the front of pedestrian crossing

\section{Discussion of the results}

We presented in the paper results of analyses related with the impact of traffic lights on the loss of time depending on the location of trams stop: in the front or behind the intersection or a pedestrian crossing. Using the results obtained, we identified the following characteristics associated with the loss of time: the mean and standard deviation of the time wasted, and the percentage of trams operated without any loss of time. Table 1 summarizes the characteristics of the time wasted. 
Tab. 1. Summary of time lost, depending on the location of the stop

\begin{tabular}{|c|c|c|c|c|}
\hline \multirow[b]{2}{*}{$\begin{array}{l}\text { Stop, } \\
\text { localization }\end{array}$} & \multirow{2}{*}{ Direction } & \multicolumn{2}{|c|}{ Lost time } & \multirow{2}{*}{$\begin{array}{l}\text { Contribution of } \\
\text { trams operated } \\
\text { without time lost } \\
{[\%]}\end{array}$} \\
\hline & & $\begin{array}{l}\text { Mean } \\
{[\mathrm{s}]}\end{array}$ & $\begin{array}{l}\text { Standard } \\
\text { deviation } \\
{[\mathrm{s}]}\end{array}$ & \\
\hline \multirow{2}{*}{$\begin{array}{l}\text { Pereca, } \\
\text { in the crossing } \\
\text { area }\end{array}$} & $\begin{array}{l}\text { Oporów, outlet of crossing } \\
\text { and behind traffic lights }\end{array}$ & 9.2 & 14.1 & 59.2 \\
\hline & $\begin{array}{l}\text { Centre, outlet of crossing and } \\
\text { in the front of traffic lights }\end{array}$ & 18.9 & 15.1 & 16.3 \\
\hline \multirow{2}{*}{$\begin{array}{l}\text { Grunwaldzki } \\
\text { Bridge, } \\
\text { in the crossing } \\
\text { area }\end{array}$} & $\begin{array}{l}\text { Grunwaldzki Square, outlet } \\
\text { of crossing and behind traffic } \\
\text { lights }\end{array}$ & 6.8 & 12.1 & 48.9 \\
\hline & $\begin{array}{l}\text { Centre, outlet of crossing and } \\
\text { in the front of traffic lights }\end{array}$ & 12.1 & 8.0 & 2.0 \\
\hline \multirow{2}{*}{$\begin{array}{l}\text { Hutmen, } \\
\text { in the area of } \\
\text { pedestrian } \\
\text { passing between } \\
\text { crossing }\end{array}$} & $\begin{array}{l}\text { Oporów, in the front of } \\
\text { pedestrian passing and traffic } \\
\text { lights }\end{array}$ & 20.2 & 9.2 & 8.2 \\
\hline & $\begin{array}{l}\text { Centre, in the front of } \\
\text { pedestrian passing and traffic } \\
\text { lights }\end{array}$ & 23.8 & 6.3 & 0 \\
\hline \multirow{2}{*}{$\begin{array}{l}\text { Bzowa, } \\
\text { in the area of } \\
\text { pedestrian } \\
\text { passing between } \\
\text { crossing }\end{array}$} & $\begin{array}{l}\text { Oporów, in the front of } \\
\text { pedestrian passing and } \\
\text { behind traffic lights }\end{array}$ & 1.7 & 5.0 & 85.7 \\
\hline & $\begin{array}{l}\text { Centre, behind pedestrian } \\
\text { passing and traffic lights }\end{array}$ & 1.8 & 3.9 & 83.7 \\
\hline
\end{tabular}

Analysing the results, it is worth to note that the average time wasted for the stop located in the front of traffic lights fluctuates around 20 seconds with exception of Grunwaldzki Bridge stop, where the average loss of time is equal to $12.1 \mathrm{~s}$. In the case of the stop located behind the intersection, the average loss of time is equal to about 8 seconds. An exception is here Bzowa stop, where analysis of the results showed an average loss of time of less than $2 \mathrm{~s}$.

Generally, the time lost for the stop at the inlet crossing (in the front of the traffic lights) is twice bigger than for stops behind the intersection. The contribution of trams operated without the lost time for stops located at the outlet of the intersection reaches 50 to $60 \%$, while for the stops at the inlet only 2 to $16 \%$. In the case of pedestrian crossings at the stops in the front of inlet the contribution is only $8 \%$, whereas for the stops behind the pedestrian passage, more than $80 \%$ of trams leave the stop without the lost time associated with services of passengers.

\section{Summary}

The study shows that due to the loss of time because of traffic lights, it is more preferable to locate the tram stops at the outlets of intersections and behind pedestrian crossings. Researches have shown that such location of stops can reduce the time lost by more than half, and also increase significantly the contribution of trams operated without time wasted. The 
next step in order to reduce the loss of time associated with the location of the stops can be a proper use of intelligent traffic control systems (ITS). The implemented calibrated detection system for tram stops behind traffic lights can significantly reduce the time lost at the entrance to the stop. On the other hand, in the case of stops located in the front of traffic lights it seems profitable to introduce modules that allow motormen to report readiness for departure on the basis of their estimate of the duration of passengers' exchange from the moment of a direct approach to the stop.

\section{Source materials}

[1] Dźwigoń W.: Warunki wymiany pasażerów na przystankach tramwajowych. Przegląd Komunikacyjny, 2012, nr 1.

[2] Kruszyna M.: Sytuowanie przystanków dla wygody pasażerów. Transport Miejski, 1996, nr 10.

[3] Makuch J.: Projektowanie przystanków tramwajowych dla bezpieczeństwa i wygody pasażerów. X Konferencja Naukowo - Techniczna „Drogi Kolejowe’99”, Spała, 1999.

[4] Makuch J., Korycki T.: Przystanki tramwajowe $\mathrm{z}$ wąskimi peronami. Przegląd Komunikacyjny, 2015, nr 10.

[5] Molecki B., Morel O.: Uwarunkowania ruchowe organizacji przesiadek w transporcie zbiorowym. Transport Miejski, 2003, nr 12.

[6] Wesołowski J.: Współczesne przystanki tramwajowe. Lokalizacja. Technika Transportu Szynowego, 2006, nr 5.

[7] Wskazówki w zakresie transportu publicznego wysokiej jakości w małych i średnich miastach, Dyrektoriat Generalny ds. Energii i Transportu Komisji Europejskiej, 2009 (p. 2.9, str. 91).

[8] Zych M.: Tramwajowe przystanki na żądanie - przegląd rozwiązań. Logistyka, 2014, nr 4/2014 -CD plate, str.3836-3846. 